\title{
Totalization, Temporalization and History: Marx and Sartre
}

\begin{abstract}
It remains the case that the totalization differs from the totality in that the latter is totalized while the former totalizes itself. In this sense, it is obvious that to totalize itself means to temporalize itself. ${ }^{1}$
\end{abstract}

This chapter picks up on what Heidegger in his 1949 'Letter on "Humanism"' calls 'the historical in being', that dimension of being within which, for Heidegger, a 'productive dialogue' between phenomenology and existentialism, on the one hand, and Marxism, on the other, 'first becomes possible.'. It introduces the possibility of this dialogue through a particular, and particularly revealing, problem with The German Ideology: namely, Marx and Engels offer no analysis of the relationship between time, temporality and their materialist concept of history. ${ }^{3}$ There are a variety of reasons why the philosophical potential of The German Ideology is far from being realized,

I Jean-Paul Sartre, Critique of Dialectical Reason, Volume r: Theory of Practical Ensembles [1960] (hereafter CDR I), trans. Alan Sheridan-Smith (London and New York: Verso, 2004), 53 .

2 Martin Heidegger, 'Letter on "Humanism"' [1949], trans. Frank A. Capuzzi, in Martin Heidegger, Pathmarks [1967], ed. William McNeill (Cambridge: Cambridge University Press, 1998), 259. For Heidegger, since 'estrangement attains an essential dimension of history' in Marx, 'the Marxist view of history is superior to that of other historical accounts' (ibid.).

3 Giorgio Agamben emphasizes this point in his Infancy \& History: Essays on the Destruction of Experience [1978], trans. Liz Heron (London and New York: Verso, 1993), 91. 
but perhaps none stands out more than the fact that this analysis is absent. As a consequence, it is unclear what a temporal reading of The German Ideology might yield, how complex practices and phenomena such as the creation of new needs, the dialectic of the forces and relations of production, the division of labour, class struggle, alienation and estrangement, are intelligible as temporal practices and temporal phenomena. The materialism of The German Ideology denotes the social activity which is labour: activity inseparable from and yet irreducible to the organic and inorganic matter which this activity creates and through which it is realized. This conception of materialism figures 'the economic' as the social production of the means of life, ${ }^{4}$ and collapses any barrier between self-transformative action by free humans [praxis] and the necessary production of objects for use [poiesis]. This is the basis from which history becomes a speculative and experimental concept in Marx. This is also the sense in which, for Marx, labour historicizes. But in what sense does labour temporalize? Put differently, how do we establish materiality and temporality, along with matter and time, as conceptually indissociable in Marx, such that the temporality of matter and the materiality of time can be thought within Marx's philosophy more generally?' To push this further, is it possible to read materiality as temporality in Marx ? $^{6}$

4. In addition to its colloquial meaning as victuals, Lebensmittel can be translated as 'means of subsistence,' 'means of existence' and 'means of life.' 'Means of subsistence' is the predominant and weakest choice, as it exclusively emphasizes the reproduction of the physical existence of individuals, a dimension which Marx's concept of life [Leben] is necessarily grounded in but profoundly expands at the same time.

5 Étienne Balibar suggests that 'Marx's philosophy, whether or not it is in a finished form, sets itself the task of thinking the materiality of timè': Étienne Balibar, The Philosophy of Marx, trans. Chris Turner (London and New York: Verso, 1995), 81.

6 William Haver goes so far as to claim that 'for Marx, materiality and temporality are the same thing.' William Haver, 'For a Communist Ontology', in Richard Calichman and John Namjun Kim, eds, The Politics of Culture: Around the Work of Naoki Sakai (London and New York: Routledge, 2010), 114. Haver does not provide it, but this reading hinges on developing a concept of materiality [Materialität] which simply put does not exist in Marx's corpus. This concept would emerge from - and yet would need to ontologically ground - Marx's critical reconstruction of materialism
These questions bring to centre stage the relationship between Marx and the philosophy of time. Specifically, they facilitate a confrontation between Marx's concept of labour in The German Ideology, a decidedly dialectical concept (internally grounded by a dialectic between the creation of the means to satisfy existing needs and the creation of new needs), and accounts of temporalization in the phenomenological and existential tradition, which are both anti-dialectical (as in the early Heidegger) and a mixture of dialectics and anti-dialectics alike (as in the later Sartre). In Heidegger and Sartre, 'temporalization' denotes the active production of a dynamic relationship between the past, the present and the future, whereas 'time' is the name for the abstract unity of these three coordinates. To put it another way, temporalization is the process of temporal differentiation: the production of the very distinction between the past, the present and the future. For Heidegger and Sartre, the concept of time does not register this process. In fact, it conceals it. For them, time is a reified category, the exteriorized product of temporalization, wherein the doubled meaning of the German Gegenwart as both presence and the present reveals itself. ${ }^{7}$ Temporalization, therefore, is ontologically basic to the ordinary concept of time. ${ }^{8}$ If this is the case, how does the temporalization of the materialist concept of history uncodify the codified tradition which is Historical Materialism? To invoke Benjamin, does the temporalization of the materialist concept of history secure its freedom from the straightjacket of historicism, from the confines of empty, homogenous time? No matter how much philosophical heterodoxy this concept implicitly entails, nor how much political agitation it explicitly

[Materialismus] in the Theses on Feuerbach as a dynamization of the subject-object relation in modern (post-Kantian) epistemology.

7 Heidegger invokes this doubled meaning across his corpus. In addition to Sartre, Althusser relies on Heidegger on this point. See Louis Althusser, 'The Errors of Classical Economics: An Outline for a Concept of Historical Time', in Louis Althusser and Étienne Balibar, Reading Capital [1968], trans. Ben Brewster (London: Verso, 1997), 95.

8 In some regards, Sartre's account of temporalization exceeds that of Heidegger's because Sartre, unlike Heidegger, situates temporalization as ontologically basic to a biological (pre-existential) time structured by the physiological needs of the human body. 
provokes, perhaps existential temporalization is what this concept of history needs, in order for Marx - this is not without irony - to realize his desire for a dissident relationship with philosophy more generally.

It is possible to justify the temporalization of the materialist concept of history on the basis that it is necessary to temporalize the concept as such in Marx, a necessity borne from the standpoint in Hegel that 'time is the concept itself, that there is.' But in what sense does temporalization destabilize the concept itself? The existential tradition is well suited to answer this question, because existential temporalization upends how we, to use a Heideggerian expression, 'initially and for the most part' understand action, activity and the act themselves. Consequently, existential temporalization intervenes into existing claims made on behalf of the originary character of The German Ideology. It intervenes, to give two notable examples, into Althusser's assertion that The German Ideology represents an 'epistemological break' and 'state of rupture' in Marx's work, ${ }^{10}$ and Georges Labica's contention that The German Ideology is a groundbreaking 'construction site' for a 'scraping operation' and 'settling of accounts' with Marx's predecessors, his contemporaries and himself. ${ }^{11}$ However, against Labica's outright reduction of all philosophy to ideology, there is a distinct possibility that philosophical discourses on temporalization might in fact enrich Marx's concept of history, and that this concept of history might in turn enrich these discourses, such that it forces these discourses to reckon with 'men and women, not in any fantastic isolation and fixation, but in their actual, empirically perceptible process of development under definite

9 G.W.F. Hegel, The Phenomenology of Spirit [1807], trans. A.V. Miller (Oxford: Oxford University Press, 1977), 487. For Hegel, this is the standpoint of absolute knowing [absolute Wissen], the pure movement of self-consciousness knowing itself as self-consciousness. Time as the concept itself is a standpoint which can only ever be taken in an open historical present. Hegel does not speak of absolute knowing as a closed or achieved content. There is, in other words, no such thing for Hegel as 'absolute knowledge'.

10 Louis Althusser, For Marx [1965], trans. Ben Brewster (London: Verso, 1996), 33 and 36.

in Georges Labica, Marxism and the Status of Philosophy [1976], trans. Kate Soper and Martin Ryle (Brighton: Harvester Press, 1980), 165-72. conditions. ${ }^{12}$ The German Ideology may convey a desire, as Althusser puts it, to 'purely and simply abolish' philosophy, ${ }^{13}$ but this desire not only 'hardly means that there is no philosophy at work in The German Ideology', ${ }^{14}$ but, we might add, hardly means that there need not be more philosophy put to work within The German Ideology. Marx's emancipatory project need not converge with Labica's militant (but not necessarily radical) reading of Marx's materialism as 'situating all philosophy, whether idealist or materialist, in its true place, namely in ideology', as rendering the notion of a Marxist philosophy 'absurd.' ${ }^{15}$ The philosophy within Marxist philosophy need not be that philosophy (i.e. classical German idealism) in opposition to which Althusser, Labica and Marx envision a 'science of history.' ${ }^{16}$ Herbert Marcuse's notion of 'concrete philosophy' is a clear example of this. For Marcuse, philosophy is 'the concrete distress of human existence ${ }^{37}$ which makes visible (and demands that we overcome) our contemporary historical situation. This philosophy, what Marcuse calls 'philosophizing' philosophy as a concrete mode of human existence - is a far cry from the abstract thought from which Althusser, Labica and Marx seek to dissociate themselves, and with which they are arguably preoccupied, to the point where they dismiss, to name the most prominent figure, the practical and concrete dimensions of Hegel's thought. To invoke Engels, perhaps it is

I2 Karl Marx and Friedrich Engels, Die deutsche Ideologie, in Karl Marx and Friedrich Engels, Marx Engels Werke, Band 3 (Berlin: Dietz Verlag, 1978), 27. The translation is mine.

I3 Louis Althusser, 'The Historical Task of Marxist Philosophy', in Louis Althusser, The Humanist Controversy and Other Writings [1966-7], ed. François Matheron, trans. G.M. Goshgarian (New York and London: Verso, 2003), 174.

I4 Ibid.

Is Labica, Marxism and the Status of Pbilosophy, 280 and 365.

16 Each in his own way, Althusser, Labica and Marx fail to engage critically the place of 'non-philosophy' within Feuerbach's Preliminary Theses on the Reform of Philosophy [1842], a place which qualifies the decisiveness and originality of their respective formulations of a science of history.

I7 Herbert Marcuse, 'On Concrete Philosophy' [1929], trans. Matthew Erlin, in Herbert Marcuse, Heideggerian Marxism, ed. John Abromeit and Richard Wolin (Lincoln: University of Nebraska Press, 2005), 36. 
not an exit from philosophy which is warranted, butan exit from the exit from philosophy. As Balibar points out, this exit is not a simple return to the inside of philosophy unburdened by history. ${ }^{18}$ It is an exit structured by a dialectic between philosophy and Marx's own foreign land (history), a foreign land which is itself already a dialectic between philosophy and non-philosophy.

This confrontation with existential temporalization cuts to the heart of the meaning of 'the human' in Marx, which is to say his distinctly social conception of human being. In Marx, the human is a social being because it is historically constituted as multiple individuals in relation to one another and those very relations themselves. ${ }^{19}$ As he states across his 1844 texts: 'social being [...] is no abstract, universal power standing over and against the individual, but is the essence of every individual [...]'; 'the individual is the social being [...] the human's individual and generic life are not different'; and 'my own existence is social activity. ${ }^{20}$ This is the basis from which history and the human are inseparable concepts in Marx. Consider, for

I8 Balibar, The Philosophy of Marx, 40 and 119.

19 The 'social' is not just direct communal relations. As Marx states: 'Social activity [...] exist [s $₫$ by no means only in the form of some directly communal activity [...] when I am active scientifically [...] when I am engaged in activity which I can seldom perform in direct community with others, then I am social, because I am active as a buman. Not only is the material of my activity given to me as a social product - as is even the language in which the thinker is active - my own existence is social activity, and therefore that which I make of myself, I make of myself for society and with the consciousness of myself as a social being': Karl Marx, Ökonomisch-philosophische Manuskripte aus dem Jahre 1844, in Marx and Engels, MEW, Band 40 (Berlin: Dietz Verlag, 1968), 538 . The translation is mine.

20 Karl Marx, Auszüge aus James Mills Buch 'Élémens d'écoñomie politique', in Marx and Engels, $M E W$, Band 40 (Berlin: Dietz Verlag, 1968), 451; Marx, Ökonomischphilosophische Manuskripte aus dem Jahre 1844, 538-9; ibid. 538. "The human, much as it may therefore be a particular individual (and it is precisely its particularity which makes it an individual and an actual individual social being), is just as much the totality - the ideal totality - the subjective existence of thought and experienced society for itself; just as it exists also in actuality as the intuition and the actual enjoyment of social existence, and as a totality of the human manifestation of life'. Ibid. 539. All translations are mine. instance, his concept of nature. For Marx, the human does not make its own history alongside a self-sufficient nature, a nature in itself and as such. Rather, human history is history as such. The idea of a 'history of nature' in isolation from the existence of living human individuals is (for Marx) unintelligible. As he puts it: 'We know only a single science, the science of history. One can look at history from two sides and divide it into the history of nature and the history of humanity. The two sides are, however, inseparable; the history of nature and the history of humans are dependent on each other so long as bumankind exists. ${ }^{21}$ And further: 'nature, the nature that preceded human history, is not by any means the nature in which Feuerbach lives, it is nature which today no longer exists anywhere [...] and which, therefore, does not exist for Feuerbach.22 Should humankind no longer exist, that would not mean that other forms of organic and inorganic matter would also not exist. Marx's claim, rather, is that these other forms of matter would be neither historical nor natural: history and nature alike come to an end with the end of human being.

Therefore, we might say that the temporalization of history is inseparable from the temporalization of the human which creates and is created by this history. But this inseparability is not grounded by nature, but rather by Marx's transhistorical concept of labour in general. As the social production of the means of life, which is a dialectical production of the means of life, labour is an ontological domain of temporalization because it constitutes the movement of negation. As in Hegel, the dialectical movement of negation is in Marx the first and most evident register of an active difference between the past, the present and the future. But is the historical status of negation thereby secured? Is negation thereby the movement of historical temporalization? The German Ideology offers

21 This passage in The German Ideology is famous, in part, because it was crossed out in a final revision of the manuscript. This translation appears in Peter Osborne, How to Read Marx (London: Granta Books, 2005), 38. Emphasis added. See also Alfred Sohn-Rethel, Intellectual and Manual Labour: A Critique of Epistemology [1970], trans. Martin Sohn-Rethel (Atlantic Highlands: Humanities Press, 1977), I8.

22 Karl Marx and Friedrich Engels, The German Ideology [1845], trans. S.W. Ryazanskaya (London: Lawrence \& Wishart, 1965), 63. 
two (deeply interwoven) dialectics as possible models of historical time: (I) the dialectic of the creation of the means to satisfy existing needs and the creation of new needs; and ( 2 ) the dialectic of the forces and relations of production. And it is negation through which the three temporal coordinates within these dialectics first becomes intelligible, such that there is futurity immanent to the present's transcendence of the past. But in what sense is the temporalization of history about more than negation? In other words, with what, or rather through what, must negation be thought in order to temporalize the materialist concept of history?

The temporalization of the materialist concept of history must situate dialectical negation in relation to historical totalization, which is to say the totalization of the time of all human lives. Whether it is openly acknowledged, left unstated or disavowed, this totalization is the overarching intelligibility and narrative of every post-Enlightenment conception of history from the mid-eighteenth century onwards. Within the modern philosophy of history, this is the sense in which the human is 'historical' because history is the development of the time of the human species as a whole. Marx does not thematize this totalization in relation to the materialist concept of history. 'World history' and the 'world-historical' figure in The German Ideology (primarily in relation to alienation and its speculative end in communism), but they are tautologically defined by Marx and Engels, ${ }^{23}$ and the extent to which they function as totalizing concepts is unclear. The world market is depicted as an integral dimension of big industry and the production bf world history 'for the first time, ${ }^{24}$ but its relation to the social production of the means of life is tenuously established, and it is clearly a phenomenon specific to capitalism. As with Marx's famous eleventh thesis on Feuerbach, ${ }^{25}$ these concepts invoke the ordinary conception of

23 'The proletariat can [...] only exist world-bistorically, just as communism, its activity, can only have a "world-historical" existence. World-historical existence of individuals means [...] [the] existence of individuals which is directly linked up with world history'. Ibid. 56.

24 Ibid. 78.

25. "The philosophers have only interpreted the world, in various ways; the point is to change it'. Karl Marx, Theses on Feuerbach [1845], in Karl Marx, Early Writings, trans. 'world', a conception which (at least on the surface) is much more about space than it is about time. Hence the 'ongoing totalization of the time of the human ${ }^{26}$ is a philosophical problem for the materialist concept of history, because the relationship between totalization and negation within this concept remains undeveloped. What is this relationship? Specifically, in what sense is totalization a kind of temporalization itself, indissociable from and yet irreducible to the movement of negation?

At this point, it is necessary to turn to the first volume of Sartre's Critique of Dialectical Reason. An existential reading of the relationship between two different materialisms in Marx (the new materialism of praxis in the Theses on Feuerbach and the historical materialism of needs in The German Ideology), Critique of Dialectical Reason systematically reconstructs dialectics as the very movement of totalization. For Sartre, it is individual praxis which ontologically grounds this reconstruction. The totalizing structure of individual praxis is, to use a Heideggerian expression, the 'originary ontological ground' of our existence, ${ }^{27}$ such that totalization becomes, to use a classical Marxist expression, the 'law of dialectics'. And it is individual praxis from which the conceptual difference between 'totalization' and 'the totality' first reveals itself. After Sartre, totalization is a ceaselessly developing activity of synthetic unification, ${ }^{28}$ whereas a totality is the exteriorized product of this activity, that which has been cut off from the totalizing process of its production (which it nonetheless contains sedimented within itself). However, this process of unification should not be understood as subsequent to an existing state of difference. There is no chronological succession here. Rather, following Heidegger, to whom Derrida's concept of différance is also indebted, totalization is

Rodney Livingstone and Gregor Benton (London and New York: Penguin Books, 1992), 423 .

26 Peter Osborne, 'Marx and the Philosophy of Time', Radical Philosophy, 147 (2008), 16.

27 Martin Heidegger, Sein und Zeit [1927], in Martin Heidegger, Gesamtausgabe, Abteilung 1: Veröffentliche Schriften 1914-1970, Band 2 (Frankfurt am Main: Vittorio Klostermann, 1977), 311 .

28 Sartre, $C D R_{1}, 46$. 
the production of difference, a unification whose unity is the process of its differentiation. However, compellingly, Sartre actively dialecticizes Heidegger's anti-dialectical philosophy of difference, and consequently represents an exception to the predominant trajectory of the philosophy of difference within twentieth-century French philosophy more generally. For our purposes, this understanding of unification grounds the basic analogy between totalization and temporalization: temporalization is, as previously argued, the production of the very difference between the past, the present and the future. ${ }^{29}$ But there is more than analogy at work here. There is a constitutive relationship of dependence. For Sartre, the totalizing structure of individual praxis totalizes precisely because it produces temporal difference. The totalizing structure of individual praxis is predicated on temporalization, just as the temporalizing structure of individual praxis is predicated on totalization. What secures this relationship of dependence? In other words, what secures the fact that individual praxis produces temporal difference as a differentiated unification?

The relationship between totalization and negation must now be addressed. For Sartre, totalization exteriorizes itself through totalities, worked matter in which praxis is embodied, but this exteriorization is always already, tied to what he characterizes as the 're-interiorization' of totalities. In other words, when an exteriorized totality is re-interiorized through individual praxis, this interiorization is the negation of the interiority of the interior.$^{30}$ For Sartre, this is why negation constitutes the essential movementof dialectics. It is why negation is squarely at the heart of the movement of totalization, but - and this is the crux of the matter - negation does not unify the time of individual praxis, because negation does not provide the standpoint from which the practical dependence between temporalization and totalization is secured. At the level of the individual act, negation produces both a difference and active relation between the

What Sartre does not examine in sufficient detail is whether the difference between totalization and the totality is analogous to the difference between temporalization and time, such that time is the exteriorized product of temporalization, cut off from its own temporalizing process, and subject to inertia.

30 Ibid. 57 past, the present and the future, but this difference and active relation is not thereby the difference and active relation which unifies the act as a differentiated unification. In Heideggerian terms, negation does not constitute the ontological meaning of 'care' [Sorge], because the temporality of negation does not constitute the meaning of the individual act as a structural whole. ${ }^{31}$ Negation is a dynamic movement in its own right, but from the standpoint of totalization negation is only temporally intelligible as a particular moment of totalization. As Sartre puts it, negation only produces 'a temporary totality [...] on the basis of a provisional totalization, ${ }^{32}$ to which we might add, 'on the basis of a provisional temporalization'.

As a consequence, Critique of Dialectical Reason enables us to develop two temporal dimensions of one and the same individual act. The first which Sartre does not thematize - is from the standpoint of dialectical negation as the internal engine of totalization. This is the sense in which a particular moment within the movement of interiorization/exteriorization can be characterized, to link up with the previous formulation in relation to Marx, as the present's transcendence of the past. This moment is a dialectical interplay between the present and the past which at the same time undeniably prioritizes the present over the past. It is the present, not the past, wherein totalization as ontologically basic to the totality, and materiality as ontologically basic to matter, becomes intelligible (for Sartre, materiality is the 'domain' of individual praxis, such that materiality becomes matter through individual praxis). We might formulate this moment as follows: the totalizing present is the dialectical negation - the

3I For Heidegger, care is the totalized manifold of existence, which he formally defines as follows: 'the being of Dasein means ahead-of-itself-being-already-in (the world) as being-alongside (entities encountered within-the-world)'. Martin Heidegger, Being and Time [1927], trans. John Macquarrie and Edward Robinson (New York: Harper Collins, 1962), 237. Heidegger establishes temporality as the ontological meaning of care in $\$ 65$ of Being and Time. As with totalization, a 'whole' should not be conflated with a totality. As Sartre states: 'a "whole" is not a totality, but the unity of the totalizing act in so far as it diversifies itself and embodies itself in totalized diversities': Sartre, $C D R \mathrm{I}, 48, \mathrm{ft} .22$.

32 Ibid. 60 
simultaneous creation and negation - of the past as a totality. Or: the materiality of the present is the dialectical negation of the past as matter. To the extent that it is embodied as matter, that is, to the extent that it is totalized as a totality, the past is fated to inertia (the totality cannot undo its separation from the process of its own production). But the past is equally fated to movement, because the totalizing present cannot totalize without re-interiorizing matter (there is no praxis without poiêsis). Hence the relationship between the present and the past is a dialectical relationship between a dialectical (totalizing) present and a non-dialectical (totalized) past. As previously stated, the future is immanent to this relationship. The future does not lie in waiting: it is not the waiting repetition of an actual dialectic played out between the totalizing present and the totalized past. Rather, the totalizing present is the future of the totalized past.

But in what sense is the future different than the present? This leads us to the second temporal dimension of the individual act, one which Sartre explicitly thematizes in Critique of Dialectical Reason. This dimension proceeds from the standpoint of totalization as such, irreducible to the negation which constitutes it, wherein the production of temporal difference - which is to say the temporal unification of the act - is not secured by negation but by the teleological structure of the act. This is the sense in which the temporality of individual praxis is defined by the particular end of a particular project: every individual act makes the future present through the imagined end of the act. To be clear, this is the teleological, not the chronological, end of the act (teleology $\neq$ chronology, the teleological end $\neq$ the chronological end) ${ }^{33}$ As with the third volume of Lukács's Ontology of Social Being, ${ }^{34}$ there is, therefore, a fundamental Aristotelian dimension to Critique of Dialectical Reason. The future as the imagined end of the act is exactly the same future as previously described: the totalizing present which is the future of the totalized past. However,

33 The fact that the teleological end $\neq$ the chronological end simply means that the goal, the intent, the aim, etc. is an imaginary structure of the act which cannot be reduced to its actual completion, finish, etc.

34 Georg Lukács, The Ontology of Social Being, Vol. III, Labour [1971-3], trans. David Fernbach (London: Merlin Press, 1978). crucially, the difference between the present and the future is not thereby flattened, because, unlike the present, the projected realization of the end of the act is not actual but imaginary. This is the sense in which the future is necessarily open: not because it does not yet exist, but because it correlates to an act of the imagination. From this perspective, the ontological priority is not the present but the future, as only the future guides the actual unification of the act, which is to say the actual differentiation between the past, the present and the future. Unification is, in a word, univocal: only the future of the act secures its temporal unity. And for Sartre, the end of the act, down to the basic 'restoration of the organism, ${ }^{35}$ is grounded by need. It is need, specifically need as it is defined by scarcity and lack, which governs the projection of the end. Hence not only does need ontologically ground the relationships between materiality and matter, temporalization and time, and totalization and the totality, but so too does it ontologically ground the relationships of dependence between these relationships, such that temporalization is not a totalization, nor does not have materiality, in isolation from human need.

The end of the individual act is one thing, but is there such a thing as the end of history (again, in the teleological, not the chronological, sense of 'end')? Is there something which provides history (as a collective singular) with its unity? What is the meaning of the historical future? The first volume of Critique of Dialectical Reason provides something of a placeholder of a response to these questions with its culminating formulation of history as a 'totalization without a totalizer. ${ }^{36}$ For Sartre, the essence of this formulation is that totalization at the level of individual praxis (a totalization whose totalizer is individual praxis) is not - it cannot be - the same totalization which totalizes history. In other words, if history is in some sense the totalization of the time of all human lives, then after Sartre it might also be conceived of as the totalization of all individual totalizations, and, therefore, as the temporalization of all individual temporaliztions. And yet historical totalization and historical temporalization are not and cannot be

5 Sartre, $C D R \mathbf{1}, 90$. 
the same totalization and temporalization which is individual totalization and individual temporalization. For Sartre, we only know totalization from the standpoint of the individual, and the totalization of all individual totalizations is history, but history is not totalized by the totalization which is individual praxis. Historical totalization is hidden. It is, after Hegel, the 'cunning of reason', an invisible hand, to invoke Adam Smith's conception of the market, which works behind the backs of individuals.

What historical totalization compels us to examine - a question which is underdetermined in Sartre and simply unasked in Marx - is the ongoing constitution of complex relationships between individual, social and historical temporalities. Take, for instance, Marx's concept of the social individual. For Marx, this individual is already and entirely determined by society, ${ }^{37}$ such that the social relation - not the individual - is the basic constituent of society. And yet, he also suggests that this individual is 'the great pillar of production and of wealth. ${ }^{38}$ At the level of the materialist concept of history, it is unclear how this concept should be read, particularly because Marx's analyses of social individuality and the social individual are completely tied to his critique of political economy (i.e. to capitalism). The point here is that it would be inadequate, if not misleading, to temporalize the social individual first and foremost from the standpoint of its individuality. But this standpoint remains the privileged point of departure within the philosophy of time. The fact is that existing discourses on temporalization are inextricably tied to the individual as the crux of that which is implicitly temporal. The individual may be a social or collective individual, as it is (to varying degrees) in Heidegger and Sartre, but the fact remains that the individual is (to date) the predominant basis of temporalization within the modern European philosophical tradition more generally. As Sartre puts it (this sentence immediately follows the quotation which frames this chapter): 'Indeed, as I have shown elsewhere, the only

37 Karl Marx, Grundrisse: Foundations of the Critique of Political Economy (Rough Draft) [1857-8], trans. Martin Nicolaus (London and New York: Penguin Books, 1993), 248.

38 Ibid. 705 . conceivable temporality is that of a totalization as an individual process. ${ }^{39}$ There is no prevailing philosophy of time which begins its account of temporalization from either the standpoint of the sociality or the historicality of the act. The philosophical tradition which we have inherited resists the possibility of theorizing temporalization from any other basis than that of the individual. The philosophy of time needs to think temporalization from an origin other than individual praxis, as in Sartre, and other than the 'in each case mineness' [Jemeinigkeit] of death, as in Heidegger. In order to be properly systematic, this philosophy must register the social and the historical as implicitly temporal in their own right, from which the complex relations between individual, social and historical temporalities can be examined in their reciprocal and asymmetric constitution.

\section{Selected Bibliography}

Althusser, Louis, For Marx [1965], trans. Ben Brewster (London: Verso, 1996).

—, and Balibar, Étienne, Reading Capital [1968], trans. Ben Brewster (London: Verso, 1997).

Balibar, Etienne, The Pbilosophy of Marx, trans. Chris Turner (London and New York: Verso, 1995).

Hegel, G.W.F., The Phenomenology of Spirit [1807], trans. A.V. Miller (Oxford: Oxford University Press, 1977).

Heidegger, Martin, Being and Time [1927], trans. John Macquarrie and Edward Robinson (New York: Harper Collins, 1962).

Labica, Georges, Marxism and the Status of Philosophy [1976], trans. Kate Soper and Martin Ryle (Brighton: Harvester Press, 1980).

Marx, Karl, Theses on Feuerbach [1845], in Marx, Early Writings, trans. Rodney Livingstone and Gregor Benton (London and New York: Penguin Books, 1992).

39 Jean-Paul Sartre, $C D R$ r, 53 . Emphasis added. The 'as I have shown elsewhere' is a reference to Jean-Paul Sartre, Being and Nothingness: An Essay on Phenomenological Ontology [1943], trans. Hazel Estella Barnes (London and New York: Routledge Classics, 2003), 130-93. 
- Grundrisse: Foundations of the Critique of Political Econamy (Rough Draft) [1857-8], trans. Martin Nicolaus (London and New York: Penguin Books, 1993).

- and Engels, Friedrich, The German Ideology [1845], trans. S.W. Ryazanskaya (London: Lawrence \& Wishart, 1965).

Sartre, Jean-Paul, Critique of Dialectical Reason, Volume r: Theory of Practical Ensembles [1960], trans. Alan Sheridan-Smith (London and New York: Verso, 2004).

\section{ADRIAN MAY}

\section{A Meteorology of the Times: Bataille, Blanchot, Lignes and the Twentieth Century}

The phenomenal success of French theory in the Anglo-American academy from the 1980 os onwards is well known, and the influence of thinkers such as Jacques Derrida, Gilles Deleuze, Michel Foucault, and more recently Alain Badiou and Jean-Luc Nancy, is palpable across the humanities and beyond. Yet one problem with the rapid importation of these texts, often read in isolation and shorn of their original context, is that the political, cultural and intellectual stakes in France, within which they were precise interventions, are often lost. An exploration of the revues in which these thinkers first published is a good way to restore the historical conjuncture and the complexity of these debates, and much work has been done on the likes of Tel Quel, Les Temps modernes and Critique to better illuminate the post-war period. ${ }^{1}$ Yet the contemporary era, from the mid-r980s to the present day (the very period of French theory's success in America and the United Kingdom), is less well known. The revue Lignes (founded in 1987), a marginal yet important milieu of contemporary thinkers, can be seen as the intellectual successor to the likes of Tel Quel and Critique, and is therefore an apt object of study to restore the material density to otherwise abstract debates.

The two key intellectual predecessors for Lignes' original editorial board were Georges Bataille (for Michel Surya and Francis Marmande) and

See, for example, Patrick ffrench, The Time of Theory (Oxford: Clarendon Press, 1995), Sylvie Patron, Critique 1946-19g6: une encyclopédie de l'esprit modern (Paris: Éditions de l'IMEC, 2000), and Anna Boschetti, The Intellectual Enterprise: Sartre and 'Les Temps modernes', trans. Richard C. McCleary (Evanston, IL: Northwestern University Press, 1988) 